\title{
Argument-Driven Inquiry, Gender, and Its Effects on Argumentation Skills
}

\author{
Neni Hasnunidah*, Wisnu Juli Wiono \\ Faculty of Education and Teacher Training, Universitas Lampung, Indonesia
}

\section{Article History: \\ Received: August $22^{\text {nd }}, 2019$ \\ Revised: September $19^{\text {th }}, 2019$ \\ Accepted: November 29th 2019 \\ Published: December $27^{\text {th }}, 2019$}

$\overline{\text { Keywords: }}$

Argument-driven Inquiry,

Argumentation Skills,

Gender

*Correspondence Address: nenihasnunidah@gmail.com

\begin{abstract}
Argumentation is considered by science teachers as a major component of science education. Middle school students need to be empowered in their argumentation skills to answer challenges to global competition. This study aimed to compare the argumentation skills between male and female students in science through the Argument-Driven Inquiry (ADI) model and guided inquiry model. There were 317 participants (150 male and 167 female) eighth-grade students of several schools in Bandar Lampung. The Pretest-posttest Non-equivalent Control Group Design was used as a part of a quasi-experimental design. The experiment class applied the ADI model and the control class applied the guided inquiry model. The data were collected by argumentation test, questionnaire of implementation learning syntax, and participant's response. The data were analyzed by ANCOVA test and qualitative techniques. The results indicated that the ADI model led to a significant increased in argumentation skills in the science context. Moreover, there is no difference in the achievement of females and males. When students were encouraged to state claims and support their claims with data, warrants, and backing, it was observed that their argumentative discourse increased in terms of both the structure and the complexity of the argumentation. In light of the findings, it is suggested that the argumentation activities should be developed to promote students' science content knowledge and argumentation skills of both male and female students.
\end{abstract}

\section{INTRODUCTION}

Improving the quality of education through formal education, including in junior high schools, is one of the most strategic efforts to improve the quality of Human Resources. UNDP (United Nations Development Program) shows that the Human Development Index (HDI) of Indonesia was 0.694 and was ranked 116 of 189 countries in the world (Prakash \& Garg, 2019). Thus, the quality of Indonesian human resources is indicated as low. The low quality of Indonesian human resources according to (Brudvik, Hong, CHEE, \& Guo, 2006), is a logical consequence of the low quality of education.

Many science education involving thinking skills can be utilized to improve the quality of Indonesian human resources (Wibawa \& Agustina, 2019). Science education is a mean for students to learn about themselves and their surroundings through active involvement in constructing their ideas when making observations, hopefully, their thinking skills will increase (Gunawan, 2017). One way to develop thinking skills is to get into the habit of arguing. The scientific argumentation skills are very important to 
be trained in science learning so that students have logical reasoning, clear views, and rational explanations of things they learned (Ginanjar, Utari, \& Muslim, 2015; Roviati, Widodo, Purwianingsih, \& Riandi, 2017).

Argumentation skills become one of the main focuses in science learning according to (Ain, Wibowo, Rohman, \& U A Deta, 2017; Probosari, Ramli, Harlita, Indrowati, \& Sajida, 2016) because students who study science must know scientific explanations about natural phenomena, use them to solve problems and be able to understand other findings they obtain. These reasons are the main driving factors so that students who understand science fully also understand the language of science and actively participate in scientific activities such as observation and argumentation. There are still many students who encounter difficulties so that active student involvement is needed in learning, especially in practicing argumentation skills (Putra, Hasnunidah, \& Jalmo, 2019).

The low argumentation skills of junior high school students in Bandar Lampung has been reviewed by several researchers (Ariyani, Nayana, Saregar, \& Pricilia, 2018; Farida, 2018; Ningtyas, 2018) and the results show that the students are not confident in expressing their opinions in front of the class, they feel they cannot convince others in accepting their opinion and do not yet have a strong data backed-up reasons. This shows that the empowerment of students' argumentation skills in schools is still not optimal.

The results of the analysis of questionnaires and interviews with the science teachers of junior high school who teach the eighth-grade students in Bandar Lampung show that less than 50\% of teachers claimed they had empowered the students' argumentation skills through the application of learning models. Most teachers used the guided inquiry model in learning. However, students were rarely involved in practical work in the laboratory. This was due to the lack of teacher's skills to manage practicum activities.

Empowerment of argumentation skills in learning science through inquiry can be done by applying the ArgumentDriven Inquiry (ADI) learning model. It is laboratory activities where students who work in experimental groups are involved in scientific argumentation (Demircioglu \& Ucar, 2012). This model is designed to make laboratory instruction more informative and includes the development of scientific arguments through research questions (Demircioglu \& Ucar, 2012). (Ginanjar et al., 2015), after applying the ADI learning model to the seventh-grade students, concluded that there was an increase in argumentation skills, both in writing and orally. Argumentation skills also increase in the tenth-grade students on work and energy material after applying the ADI learning model (Kurniasari, 2017; Hanifah \& Admoko, 2019) .

Gender issues have long received attention by researchers in education (Kost, Pollock, \& Finkelstein, 2009; Lee, Capraro, Bicer, \& Capraro, 2019). (Katminingsih \& Widodo, 2015) found that there were differences in students' creative thinking abilities in terms of genders after applying a problem-based learning model. (Afriana, Permanasari, \& Fitriani, 2016) found that the scientific literacy skills of male and female students after the application of the STEM learning model similarly demonstrated an increase in N-gain, respectively 0.36 and 0.31 . (Hodiyanto, 2017), after applying the problem-solving learning model, concluded that there were no differences in communication skills between male and female students. (Celep, 2015) also found that there were no differences in attitudes towards chemistry and understanding of gas between male and female students after applying the 
Argument-Driven Inquiry (ADI) learning model.

This study will examine the Argument-Driven Inquiry (ADI) learning model and Guided Inquiry on students' argumentation skills and see the influence of gender. This learning model involves a series of laboratory activities that arouse the active participation of students in argumentation discourse and accustom students to develop critical thinking through the process of building arguments and communicating productively through writing.

\section{METHOD}

This study employed the quasiexperimental design that is the Pretestposttest Non-equivalent Control Group Design. The independent variable in this study is the learning model, the dependent variable is the argumentation skills, while the moderate variable is gender. In detail, the draft plan in this study is presented in Table 1.

Table 1. Study Design 2 x 2 Factorial

\begin{tabular}{|c|c|c|}
\hline \multirow{2}{*}{ Gender } & \multicolumn{2}{|c|}{ Learning Models (M) } \\
\hline & ADI (M) & GI (M2) \\
\hline Male $\left(\mathrm{G}_{1}\right)$ & $\mathrm{M}_{1} \mathrm{G}_{1}$ & $\mathrm{M}_{1} \mathrm{G}_{2}$ \\
\hline Female $\left(\mathrm{G}_{2}\right)$ & $\mathrm{M}_{2} \mathrm{G}_{1}$ & $\mathrm{M}_{2} \mathrm{G}_{2}$ \\
\hline \multicolumn{3}{|l|}{ Description: } \\
\hline ADI $=$ Argum & Driven Inqu & \\
\hline = Guidec & uiry & \\
\hline
\end{tabular}

This research was conducted in four SMP/MTsN (Junior High School) in Bandar Lampung. The population of this study was all students of SMPN/MTsN in Bandar Lampung. The samples of this study were 317 students (150 male and 167 female) of the second semester of the 2018/2019 academic year. The samples were randomly selected by conducting a consistency test using ANOVA beforehand. The consistency test results were obtained from the results of the ninth-grade students' national examination. This research was conducted in 2 different classes from 4 different schools with different learning models.
The instrument for measuring the argumentation skills in this study was an essay test developed concerning the competing theories strategy by (Erduran, Simon, \& Osborne, 2004). The argumentation discourse data was generated from the analysis of students' answers using TAP (Toulmin Argumentation framework Pattern), as shown in Table 2.

Table 2. Rubric for Determining Argumentation Skills

\begin{tabular}{|c|c|}
\hline Scores & Criterion \\
\hline 5 & $\begin{array}{l}\text { Arguments present an extended } \\
\text { argument with more than one clear } \\
\text { refutation. }\end{array}$ \\
\hline 4 & $\begin{array}{l}\text { The argument shows an argument } \\
\text { with a clear refutation and has several } \\
\text { claims and counterclaims. }\end{array}$ \\
\hline 3 & $\begin{array}{l}\text { Arguments contain arguments with a } \\
\text { series of claims or counterclaims with } \\
\text { weak data, warrants or backing, and } \\
\text { refutation. }\end{array}$ \\
\hline 2 & $\begin{array}{l}\text { Arguments contain arguments from } \\
\text { one claim against another claim with } \\
\text { data, warrant, or backing but do not } \\
\text { contain any rebuttal. }\end{array}$ \\
\hline 1 & $\begin{array}{l}\text { The argument contains an argument } \\
\text { with a simple claim against a claim } \\
\text { that contradicts (counterclaim) or a } \\
\text { claim against other claims. }\end{array}$ \\
\hline
\end{tabular}

(Modified from Osborne et al., 2004)

To facilitate the assessment of students' argumentation skills based on the TAP framework, a coding system based on linguistic features proposed by (Brudvik et al., 2006) was used. The coding system is displayed in Table 3.

Table 3. Argumentative Assessment Coding

\begin{tabular}{ccl}
$\begin{array}{c}\text { Codes } \\
\text { Letter }\end{array}$ & Interpretation & Linguistic Features \\
\hline K / & Claim/ & I agree with ...; I \\
& Counter & support ... $;$ In my \\
Claim & $\begin{array}{l}\text { opinion ... it's right, or } \\
\text { I do not agree ... I } \\
\text { disagree with ... ; In } \\
\text { my opinion ... not } \\
\text { according to }\end{array}$ \\
& & I agree with ... \\
& & because ... Why I \\
& & support ... because ... \\
& The thing that makes
\end{tabular}




\begin{tabular}{|c|c|c|}
\hline $\begin{array}{l}\text { Codes } \\
\text { Letter }\end{array}$ & Interpretation & Linguistic Features \\
\hline \multirow[b]{2}{*}{ B } & & me disagree is ... \\
\hline & Backing & $\begin{array}{l}\text { Based on what I have } \\
\text { experienced ...; } \\
\text { According to what is } \\
\text { in the book ... If we } \\
\text { look at the facts about } \\
\text {.. From the theory I } \\
\text { read ... ; I've heard of } \\
\ldots \text {; The following } \\
\text { phenomena/data/facts } \\
\text { prove ... }\end{array}$ \\
\hline $\mathrm{R}$ & Rebuttal & $\begin{array}{l}\text { I disagree ...; I } \\
\text { disagree with ... ; In } \\
\text { my opinion ... not } \\
\text { appropriate; Your } \\
\text { statement seems } \\
\text { inappropriate ... }\end{array}$ \\
\hline RW & $\begin{array}{c}\text { Rebuttal to } \\
\text { warrant }\end{array}$ & $\begin{array}{l}\text { I do not agree with } \\
\text { your reasons ...; The } \\
\text { basis you put forth } \\
\text { does not seem to } \\
\text { support ... }\end{array}$ \\
\hline $\mathrm{RB}$ & $\begin{array}{c}\text { Rebuttal to } \\
\text { Backing }\end{array}$ & $\begin{array}{l}\text { I agree with the reason } \\
\text { only the data about ... } \\
\text { which is not right ... }\end{array}$ \\
\hline
\end{tabular}

(Roshayanti, 2012)

Before the argumentation skills test was used, validity and reliability tests were performed. The validity test was done by employing the product-moment correlation formula using raw numbers. The reliability test was done by employing the Cronbach Alpha formula. Both calculations were assisted by SPSS software version 20 for Windows.

The implementation of natural science learning through the ADI model was carried out in 15 meetings in one semester, with 5 main subjects, namely: the motion system, the digestive system, the respiratory system, light, and simple aircraft. The syntax of the ADI learning model and Guided Inquiry (GI) is shown in Table 4.
Table 4. Learning Steps of ADI and GI Models.

\begin{tabular}{|c|c|c|}
\hline $\begin{array}{c}\text { Learning } \\
\text { Steps of }\end{array}$ & ADI & GI \\
\hline 1 & $\begin{array}{l}\text { Identifying the } \\
\text { tasks }\end{array}$ & Observation \\
\hline 2 & $\begin{array}{l}\text { Collecting the } \\
\text { data }\end{array}$ & $\begin{array}{l}\text { Formulating } \\
\text { problems }\end{array}$ \\
\hline 3 & $\begin{array}{l}\text { Producing } \\
\text { tentative } \\
\text { arguments }\end{array}$ & $\begin{array}{l}\text { Proposing } \\
\text { hypotheses }\end{array}$ \\
\hline 4 & $\begin{array}{l}\text { Interactive } \\
\text { sessions of } \\
\text { arguments }\end{array}$ & $\begin{array}{l}\text { Collecting } \\
\text { data }\end{array}$ \\
\hline 5 & $\begin{array}{l}\text { Preparing written } \\
\text { inquiry reports }\end{array}$ & $\begin{array}{l}\text { Analyzing } \\
\text { data }\end{array}$ \\
\hline 6 & $\begin{array}{l}\text { Reporting the } \\
\text { review }\end{array}$ & Concluding \\
\hline 7 & $\begin{array}{l}\text { Reporting the } \\
\text { revisions }\end{array}$ & \\
\hline 8 & $\begin{array}{l}\text { Reflecting } \\
\text { through } \\
\text { discussions }\end{array}$ & \\
\hline
\end{tabular}

The data of students' argumentation skills in this study were analyzed by employing the ANCOVA test. A further test was done using the LSD test (Least Significant Difference) at a 5\% significance level. Before the data was tested with ANCOVA, the prerequisite tests of normality and homogeneity tests were performed. The normality was tested using the Kolmogorov-Smirnov OneSample Test and the homogeneity was tested using the Levene Test of Equality of Variances Error, each at a 5\% significance level. The data were analyzed with the help of SPSS version 21 for Windows.

\section{RESULT AND DISCUSSION}

The results showed that there are different influences in the argumentation skills achievement between students who learned using the ADI learning model and students who learned using the guided inquiry. Meanwhile, both the effect of gender and the effect of interaction between learning models and gender are not significant. The complete results are presented in Table 5. 
Table 5. Test Results of the Effect of Learning Models, Gender, and Their Interaction on Students' Argumentation Skills

\begin{tabular}{lrrrrr}
\hline \multicolumn{1}{c}{ Source } & \multicolumn{1}{c}{$\begin{array}{c}\text { Type III Sum of } \\
\text { Squares }\end{array}$} & Df & Mean Square & \multicolumn{1}{c}{ F } & \multicolumn{1}{c}{ Sig. } \\
\hline Corrected Model & $44587.881^{\text {a }}$ & 11146.970 & 4 & 66022 & 0000 \\
Intercept & $48616,303287,949$ & 1 & & 48616,303 & 0,000 \\
Pretest & $9616,58756,958$ & 1 & & 9616,587 & 0,000 \\
Model & $29402,981174,151$ & 1 & & 29402,981 & 0,000 \\
Gender & $221,9180,252$ & 1 & & 1,314 & 221,918 \\
Model * Gender & $193,1550,286$ & 1 & & 1,144 & 193,155 \\
Error & 52676.927 & 312 & 168836 & & \\
Total & 1345629.000 & 317 & & & \\
Corrected Total & 97264,808 & 316 & & & \\
\hline
\end{tabular}

a. R Squared $=0.458$ (Adjusted R Squared $=0.451$ )

b. Computed using alpha $=0.05$

Based on Table 5, the statistical value of $F=174.15$ at a significance value of 0.00 . Thus, the ADI learning model has a real influence on the achievement of students' argumentation skills. The comparison of the mean value of argumentation skills for both models based on a complete LSD test is presented in Table 6.

Table 6. Comparison of Corrected Mean Values of Argumentation Skills on Both Learning Models

\begin{tabular}{cccccc}
\hline \multirow{2}{*}{ Model } & \multicolumn{4}{c}{ Mean Value } & \multirow{2}{*}{ Notation } \\
\cline { 2 - 5 } & Initial & Final & Difference & Corrected & \\
\hline ADI & 38.08 & 72.59 & 34.51 & 72.08 & $\mathrm{a}$ \\
GI & 35.78 & 51.92 & $16: 13$ & 52.67 & $\mathrm{~b}$ \\
\hline
\end{tabular}

* The mean difference is significant at the 0.05 level

Referring to Table 6, it can be said that with a difference of 19.40, the average argumentation skills of students in the ADI group were higher than those in the GI group in the argumentation skills achievement.
A comparison of the corrected mean value of argumentation skills for the two gender groups based on the LSD test is presented in Table 7. The corrected mean value of the argumentation skills of male students is only 1.69 which is lower than female students.

Table 7. Comparison of Corrected Mean Values on Argumentation Skills on Both Genders

\begin{tabular}{cccccc}
\hline \multirow{2}{*}{ Learning Models } & \multicolumn{4}{c}{ Mean Value } & \multirow{2}{*}{ Notation } \\
\cline { 2 - 5 } & Initial & Final & Difference & Corrected & \\
\hline Male & 35.63 & 60.70 & 25.07 & 61.53 & $\mathrm{~A}$ \\
Female & 38.23 & 63.81 & 25.58 & 63.22 & $\mathrm{a}$ \\
\hline
\end{tabular}

The comparison of the corrected mean value of argumentation skills between the male and female students in the two learning models is presented in Table 8. Based on Table 8, it is known that the highest value of argumentation skills belongs to the female students in the ADI group. The lowest corrected mean value belongs to the male students in the GI group. 
Table 8. Corrected Mean Value on Argumentation Skills of Male and Female Students on Both Learning Models

\begin{tabular}{|c|c|c|c|c|c|c|}
\hline \multirow{2}{*}{ Learning Models } & \multirow{2}{*}{ Gender } & \multicolumn{3}{|c|}{ Mean Value } & \multirow{2}{*}{ Corrected } & \multirow{2}{*}{ Notation } \\
\hline & & Initial & Final & Difference & & \\
\hline \multirow{2}{*}{ ADI } & Male & 35.90 & 69.86 & 33.96 & 70.45 & $\mathrm{a}$ \\
\hline & Female & 40.26 & 75.31 & 35.06 & 73.70 & $\mathrm{a}$ \\
\hline \multirow{2}{*}{ GI } & Male & 35.37 & 51.54 & 16.17 & 52.61 & $\mathrm{a}$ \\
\hline & Female & 36.20 & 52.30 & 16.10 & 52.73 & $\mathrm{a}$ \\
\hline
\end{tabular}

Covariates appearing in the model are evaluated at the following values: Pretest $=37.06$.

Based on the results of the analysis shown in Table 5 and Table 6 , it can be seen that the ADI learning model has a significant effect on argumentation skills. The average score of students' argumentation skills in learning with ADI is higher than Guided Inquiry (GI). It can be said that the ADI learning model is more effective in improving argumentation skills than guided inquiry. The increase can be understood as the impact of the learning model used. The results of this study support several similar studies, namely: (Demircioglu \& Ucar, 2012) researched primary school science teachers at a University in Turkey. The results show that the ADI model is more effective in improving the quality of argumentation compared to traditional practicum methods; Furthermore, Huda (2014) in his research on the ninth-grade students of junior high school in Garut City concluded that the application of the ADI model with the science investigation method increase students' argumentation skills.

ADI learning model in this study significantly improved students' argumentation skills. ADI learning model is proven to be able to train students' skills in developing high-quality arguments. Arguing through the ADI model encourages students to make ideas, evidence, and reasoning related to one another, then argue to evaluate ideas and find the most valid or acceptable explanation. For example, students are given the following problem.
Two students are discussing a disturbance in the motion system. Each student concludes that: Student 1:

Rickets is caused by a wrong habitual posture.

Student 2:

Rickets is caused by vitamin D deficiency.

Question:

Which student's argument do you agree with? Explain your reasons by using the facts below. Then, which student argument do you disagree with?

Also, use the facts below to make the right reasons.

a. Vitamin $D$ is useful for keeping bones solid.

b. Rickets causes bone loss in adults.

c. People aged 1-70 years need vitamin D as much as $15 \mathrm{mg} /$ day meanwhile people aged 71 years and over need $20 \mathrm{mg} /$ day.

d. Rickets results in impaired bone growth so that the shape of the foot bends out (in the form of the letter $X$ ) or bends inward (in the form of the letter 0 ).

e. Osteomalacia is the rickets term suffered by adults.

Most students can answer the question correctly, like this example:

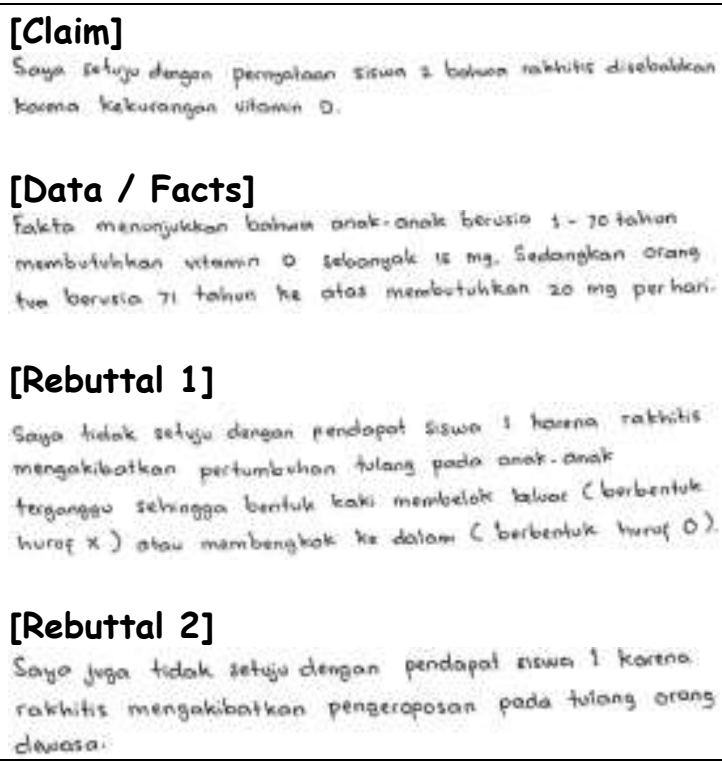


The results show that students who learn through the ADI model answered with complete argument construction, namely stating claims, data/warrant/ backing, and rebuttal. This result is consistent with the conclusions by (Erduran et al., 2004) that the quality of arguments can be determined by the presence or absence of rebuttal or counter-argument in the argumentation discourse. Arguments with refutation are important elements of quality arguments and show a high level of argumentation skills.

The findings of this study also indicate that students who learn through the guided inquiry have lower achievement in argumentation skills compared to students in the ADI group. Based on the analysis of their answers, the explanation they made was incomplete because it was only based on claims with data/warrant/backing, and even without rebuttal. The results of this study support the results of (Bell, 2010) study, which concluded that students tend to only present data to support their claims, not by warrant or backing. Jimenez et al. (2007) in his research, found that students were more focused on making detailed claims without data or warrant in developing their arguments (Osborne, Erduran, \& Simon, 2004).

The results of this study also revealed that the argumentation skills of eighth-grade students in science subjects did not differ in terms of gender. In other words, the ADI learning model does not lead to gender bias. The results of this study support the conclusion of (Celep, 2015), which states that the ADI learning model does not affect differences in understanding of the concept of gas and attitudes towards chemistry in male and female students.

The absence of real interaction between learning models and gender on argumentation skills shows that the independent variables (learning models) and moderator variables (gender) carry more significant separate effects on the dependent variable (argumentation skills). Also, the lack of interaction is strongly suspected by the absence of dominance between learning models and gender over argumentation skills. This is in line with what was stated by Hair et al. (1998) that no interaction is caused if two or more independent variables carry significant separate effects toward the dependent variable.

The lack of interaction between learning models and gender on argumentation skills can also be traced from the syntax of ADI. There are argument production and interactive argument sessions (third and fourth steps) that allow all group members, both male and female students, to make arguments and express them comfortably. This is different from the syntax in the GI learning model which does not provide learning steps that facilitate students to make and express arguments.

\section{CONCLUSION}

The main objective of this study is to explore the influence of learning models, gender, and their interaction toward argumentation skills. Based on the discussion, it can be concluded that learning based on the activities of inquiry, argumentation, writing, and reviewing positively influences the argumentation skills of the eighth-grade students of junior high schools in Bandar Lampung on scientific concepts. The increase in the mean value of students' argumentation skills in the experimental group (ADI = $91 \%$ ) was higher than the control group $(\mathrm{GI}=45 \%)$.

The second main finding of this study is that the argumentation skills of male students in the ADI group were not significantly different than those of female students. After 15 science learning meetings with both the ADI and GI models, the average argumentation skills 
between male and female students were very similar $(\mathrm{ADI}$ male $=70.48$; $\mathrm{ADI}-$ female $=73.70 ;$ GI male $=52,61$; GIfemale $=52.73$ ) .

\section{REFERENCES}

Afriana, J., Permanasari, A., \& Fitriani, A. (2016). Implementation ProjectBased Learning Integrated STEM to Improve Scientific Literacy Based on Gender. Jurnal Inovasi Pendidikan IPA, 2(2), 202-212.

Ain, T. N., Wibowo, H. A. C., Rohman, A., \& U A Deta. (2017). The Scientific Argumentation Profile of Physics Teacher Candidate in Surabaya. Seminar Nasional Fisika, 997.

Ariyani, F., Nayana, T., Saregar, A., Yuberti, Y., \& Pricilia, A. (2018). Development of Photonovela with Character Education: As an Alternative of Physics Learning Media. Jurnal Ilmiah Pendidikan Fisika Al-Biruni, 7(2), 227. https://doi.org/10.24042/jipfalbiruni. v7i2.3072

Bell, P. (2010). Scientific Arguments as Learning Artifacts: Designing for Learning from The WEB with KIE. International Journal of Science Education, 22(8), 797-817. https://doi.org/10.1080/09500690041 2284

Brudvik, O. C., Hong, K. S., CHEE, Y. S., \& Guo, L. (2006). Assessing the Impact of a Structured Argumentation Board on the Quality of Students 'Argumentative Writing Skills. Proceedings of the 14th International Conference on Computers in Education, 141-148.

Celep, N. D. (2015). The Effects of Argument-Driven Inquiry Instructional Model on 10th Grade Students' Understanding of Gases Concepts. Gazi University.

Demircioglu, T., \& Ucar, S. (2012). The Effect of Argument-Driven Inquiry on Pre-Service Science Teachers'
Attitudes and Argumentation Skills. Procedia - Social and Behavioral Sciences, 46, 5035-5039. https://doi.org/10.1016/j.sbspro.2012 .06 .382

Erduran, S., Simon, S., \& Osborne, J. (2004). TAPping into Argumentation: Developments in the Application of Toulmin ' $\mathrm{s}$ Argument Pattern for Studying Science Discourse. Wiley Interscience.

https://doi.org/10.1002/sce.20012

Farida, L. A., Rosidin, U., Herlina, K. \& Hasnunidah, N. 2018. Pengaruh Penerapan Model Pembelajaran Argument-Driven Inquiry (ADI) Terhadap Keterampilan Argumentasi Siswa SMP Berdasarkan Perbedaan Jenis Kelamin. Journal of Physics and Science Learning, 02(2): 25-36.

Ginanjar, W. S., Utari, S., \& Muslim. (2015). Penerapan Model ArgumentDriven Inquiry dalam Pembelajaran IPA untuk Meningkatkan Kemampuan Argumentasi Ilmiah Siswa SMP. Jurnal Pengajaran MIPA, 20(1), 3237.

Gunawan, G. (2017). Keterampilan Berpikir dalam Pembelajaran Sains. (L. Herayanti, Ed.). Lombok Barat: Penerbit Arga Puji Press.

Hair, J.F., Anderson, R.E., Tatham, R.L. \& Black, W.C. 1998. Multivariate Data Analysis. Fifth Edition. New Jersey: Prentice-Hall.

Hanifah, N., \& Admoko, S. (2019). Penerapan Model Pembelajaran Argument Driven Inquiry (ADI) untuk Melatihkan Kemampuan Argumentasi Ilmiah Peserta Didik SMA. Inovasi Pendidikan Fisika, 08(02), 593-597.

Hodiyanto, H. (2017). Pengaruh Model Pembelajaran Problem Solving Terhadap Kemampuan Komunikasi Matematis Ditinjau dari Gender. Jurnal Riset Pendidikan Matematika, 4(2), 219-228. 
Huda, F. N. 2014. Pengaruh Penerapan Model Pembangkit Argumen dengan Metode Investigasi Sains terhadap Peningkatan Kemampuan Argumentasi Siswa pada Materi Fluida Statis. Skripsi. Universitas Pendidikan Indonesia.

Jimenez-Aleixandre, M. P., \& S. Erduran. 2007. Argumentation in science education: An overview. Netherlands: Springer

Katminingsih, Y., \& Widodo, S. (2015). Pengaruh Model Pembelajaran Berdasarkan Masalah terhadap Kemampuan Berpikir Kreatif Matematis Siswa Ditinjau Menurut Gender Siswa Sd Negeri Tarokan Kediri. Jurnal Math Educator Nusantara, 1(1), 77-89.

Kurniasari, S.I. K. A. (2017). Penerapan model pembelajaran argument driven inquiry (ADI) untuk melatihkan kemampuan argumentasi ilmiah siswa pada materi usaha dan energi. Inovasi Pendidikan Fisika, 6(3).

Kost, L. E., Pollock, S. J., \& Finkelstein, N. D. (2009). Characterizing the gender gap in introductory physics. Physical Review Special Topics Physics Education Research, 5(1), $1-14$.

https://doi.org/10.1103/physrevstper. 5.010101

Lee, Y., Capraro, R. M., Bicer, A., \& Capraro, R. M. (2019). International Journal of Mathematical Education in Gender difference on spatial visualization by college students , major types as STEM and nonSTEM : a meta-analysis major types as STEM and non-STEM : a metaanalysis. International Journal of Mathematical Education in Science and Technology, $O(0), \quad 1-15$. https://doi.org/10.1080/0020739X.20 19.1640398

Ningtyas, N. 2018. Pengaruh Model Argument-Driven Inquiry (ADI) Pada Pembelajaran Sistem Pencernaan
Pada Manusia Terhadap Keterampilan Argumentasi Siswa SMP Negeri 13 Bandar Lampung Berkemampuan Akademik Berbeda. Skripsi. Universitas Lampung.

Osborne, J., Erduran, S., \& Simon, S. (2004). Enhancing The Quality of Argumentation in School Science. Journal of Research in Science Teaching, 1-40.

Prakash, R., \& Garg, P. (2019). Comparative assessment of HDI with Composite Development Index ( CDI ). Insights Regional Development, 1(1), 58-76.

Probosari, R. M., Ramli, M., Harlita, Indrowati, M., \& Sajida. (2016). Profil Keterampilan Argumentasi Ilmiah Mahasiswa Pendidikan Biologi FKIP UNS pada Mata Kuliah Anatomi Tumbuhan. Bioedukasi, 9(1), 29-33.

Putra, D. J., Hasnunidah, N., \& Jalmo, T. (2019). Pengaruh Argument Driven Inquiry Terhadap Keterampilan Argumentasi Siswa pada Materi Sistem Pernapasan. Jurnal Bioterdidik, 7(1), 1-10.

Roshayanti, F. (2012). Pengembangan Model Asesmen Argumentatif Untuk Mengukur Keterampilan Argumentasi Mahasiswa Pada Konsep Fisiologi Manusia. Universitas Pendidikan Indonesia, Bandung.

Roviati, E., Widodo, A., Purwianingsih, W., \& Riandi, R. (2017). Perceptions of Prospective Biology Teachers on Scientific Argumentation in Microbiology Inquiry Lab Activities. International Conference on Mathematics and Science Education, 895.

Sulisworo, D. (2016). The Contribution of the Education System Quality to Improve the Nation's Competitiveness of Indonesia. Journal Od Education and Learning, $10(2)$,

127-138. 
https://doi.org/10.11591/edulearn.v1 $0 \mathrm{i} 2.3468$

Wibawa, R. P., \& Agustina, D. R. (2019). Peran Pendidikan Berbasis Higher Order Thinking Skills (HOTS) pada Tingkat Sekolah Menengah Pertama di Era Society 5.0 sebagai Penentu Kemajuan Bangsa Indonesia. Equilibrium, 7(2), 137-141. 